\title{
Studentification, diversity and social cohesion in post-socialist Budapest
}

\author{
Szabolcs FABUla ${ }^{1}$, Lajos BOROS ${ }^{1}$, Zoltán KOV ÁCS ${ }^{2}$, Dániel HORV ÁTH ${ }^{1}$ and \\ VIKTOR PÁL ${ }^{1}$
}

\begin{abstract}
In the literature studentification is closely associated with gentrification. Many authors consider the mass invasion of students to inner-city neighbourhoods as a type of gentrification, some of them even use the two terms interchangeably. Regardless of theoretical considerations, it seems that there is a consensus on the significance of studentification in contemporary urban transformations. Recent studies demonstrate that the appearance of students as 'transient' inhabitants in inner-city neighbourhoods, accompanied by growing differences in lifestyles and socio-cultural attitudes weakens social cohesion in the affected neighbourhoods HAASE, A. et al. 2012). This study focuses on the interplay between studentification, socio-cultural diversity and social cohesion in an inner-city district of Budapest, Józsefváros. The district has been characterised by several waves of urban rehabilitation and subsequent gentrification since the transition of 1989-1990. Studentification has also become dominant phenomenon in the area due to the settling of new higher education institutions, the concomitant influx of students, as well as low rent and dwelling prices providing a niche for the spontaneous movements of a new generation of urbanites (Grabkowska, M. 2011; Bernt, M. et al. 2015). The main research questions we intend to answer in this paper are as follows. Firstly, what is the relationship between studentification and gentrification in Józsefváros? Secondly, what kinds of effects has the influx of students on the social cohesion of the district? According to our findings, studentification in Józsefváros is not the pioneer phase of gentrification, but - especially in the rehabilitation areas - it runs more or less parallel with it. Most of the students use the place as a springboard in their career, and after graduation most of them leave. The attitude of students is, however, very much resembles those of the young, highly educated newcomers, i.e. early gentrifiers. The impacts of studentification on the social milieu of Józsefváros are contradictory. On the one hand, the inflow of students and young intellectuals increases the socio-cultural diversity of the district, contributing to the recognition of diversity in a post-socialist context, and fostering tolerance and the acceptance of different cultures and lifestyles. On the other hand, it seems that the ongoing population change hampers the establishment of strong social ties at the neighbourhood level and leads to certain conflicts.
\end{abstract}

Key words: studentification, gentrification, social diversity, social cohesion, post-socialist city

\section{Introduction}

The global expansion of higher education, the unprecedented growth in the number of students and their growing impacts on urban space have attracted increasing attention in the literature. Areas with distinct sociocultural, economic and physical features are emerging in our cities due to the growing presence of students, and the concomitant rise of specific, student-oriented services (e.g. housing, retail, leisure, etc.) (SмIтн, D.P. 2002; RugG, J. and Rhodes, D. 2003; Allinson, J. 2006; Hubbard, P. 2009; Coulter, R. et al. 2015). In the literature this process has been widely recognised and labelled as 'studentification'. This is a contradictory process with costs and benefits varying from one locality

\footnotetext{
${ }^{1}$ Department of Economic and Social Geography, University of Szeged, H-6722 Szeged, Egyetem u. 2. E-mail: fabula.szabolcs@geo.u-szeged.hu (Corresponding author)

${ }^{2}$ Department of Economic and Social Geography, University of Szeged; Geographical Institute, Research Centre for Astronomy and Earth Sciences, MTA. H-1112 Budapest, Budaörsi u. 45. E-mail: zkovacs@iif.hu
} 
to another. The presence of students has several beneficial effects on neighbourhoods, however, this can also be a source of conflicts (Russo, A.P. et al. 2003; Sмітн, D.P. 2008). As the British HMO Lobby (2008) interpreted: studentification is the 'substitution of a local community by a student community', which can also be called as 'student ghetto' because of the strong isolation of student areas from the rests of the cities (SмiтH, D.P. 2002; HubBard, P. 2008).

As for our context, it is important to emphasise that studentification has evolved in postsocialist countries differently from the West because of historical legacies and path dependencies (Grabkowska, M. 2011; Gentile, M. et al. 2012; HAAse, A. et al. 2012; GórCZYŃsKA, M. 2014, 2017; JАко́вСZYк-GrYsZKIEwicz, J. et al. 2014; BERnt, M. et al. 2015). Due to the elitist nature of state-socialist policy on higher education the number and relative weight of students remained low in these societies. The systemic changes of 1989-1990 meant an abrupt change also in this field. Since 19891990 the number of students enrolled in higher education has rapidly expanded, existing universities have been enlarged, new higher education institutions have been established all over Central and Eastern Europe. All these changes gave rise to a substantial pool of potential student-gentrifiers, i.e. students who seek inner-city locations close to their universities and other typically student facilities (KRIŠJĀNe, Z. and BĒRZIN̦š, M. 2014; BERnT, M. et al. 2015; K̈̈HRIK, A. et al. 2016).

The growing body of literature on gentrification and studentification in post-socialist cities has highlighted so far, that compared to the West, students in post-socialist cities are more dispersed throughout the whole city; they concentrate not only in close to inner-city locations, but they also tend to reside at large housing estates with good location and transport connections (GrabKowsKa, M. 2011; Grabkowska, M. and Frankowski, J. 2016). Moreover, leisure spaces of students and local residents are not always separated from each other. Instead, an overlap among the activity spaces of students, local residents and tourists can be observed, which lowers the level of segregation and decreases the chances of conflicts between students and other social groups (MurzyN-Kupisz, M. and SzmyткоwsкA, M. 2015). In this respect it is an intriguing question how studentification under post-socialist conditions can contribute to urban diversity and what the general perceptions of the process are among local residents and policy-makers.

In this paper we intend to focus on the interplay between studentification, urban diversity and social cohesion on the example of Józsefváros, Budapest. Budapest (1.7 million inhabitants) is the capital city and the main higher education centre of Hungary, with high concentration of higher education institutions (HEI) where the number of enrolled students exceeded 136 thousand in 2014 [1]. Within Budapest Józsefváros has become the target of urban regeneration activities coupled with large-scale university development programmes after the late 1990s. The local society has been permanently changing due to the arrival of a variety of social groups, including students. The gradual upgrading of the district and the growing diversity of the local society bringsus to the following research questions:

- What is the relationship between studentification and gentrification in Józsefváros? Is studentification the initial phase of gentrification as implied in the literature or gentrification and studentification are taking place side by side?

- How does the influx of students and other young people affect the social cohesion the local society? What types of potential conflicts emerge due to their mass arrival?

\section{Theoretical background}

Studentification is often discussed in the literature in relation to gentrification (e.g. Sмiтh, D.P. 2004, 2005; Sмiтh, D.P. and Holt, L. 2007). Can studentification be con- 
sidered as a first step to gentrification? Are students the future gentrifiers who learn and practice the culture of gentrification when living in student neighbourhoods? These are fundamental questions from the perspective of the present study. Studentification, similarly to gentrification often leads to the displacement of long-term residents and the increase of property prices. In some analyses, students are considered as 'apprentice' gentrifiers, who contribute to the rising prestige of neighbourhoods through enhancing their aesthetic and cultural capital (SмIтH, D.P. 2002, 2005; Sмiтh, D.P. and Holt, L. 2007; Davidson, D. 2009; Murzyn-Kupisz, M. and SzmyткоwsкA, M. 2015). Thus, similarly to artists, students are also often considered to be the pioneers of gentrification (ZUKIN, S. 1989; LEY, D. 2003).

However, as opposed to gentrification, studentification does not necessarily lead to a long-term upgrading of neighbourhoods; the initial upgrading process can often be followed by downgrading. Moreover, studentification can further reinforce marginality and the negative image of a neighbourhood, strengthening already existing problems (SAGE, J. et al. 2012a). The motivations of the actors of gentrification and studentification are also different; students' housing decisions are normally based on consumption and leisure preferences rather than the exploitation of rent gap. Therefore, studentification also often takes place in better-off, middle-class neighbourhoods and not only in downgraded quarters (MurzYN-Kupisz, M. and Szmytкowska, M. 2015).

According to Sмiтн (2002) and SмIтH and Holt (2007) changes generated by studentification have four basic dimensions: economic, social, cultural and physical. The economic dimension refers to changes like the revalorisation of the housing stock, the growing significance of renter-occupancy or - since short-term rental becomes dominant on the housing market instead of long-term rental - the emergence of speculative investments (RUGG, J. et al. 2002; SмIтH, D.P. 2008).
The social dimension includes, for example, changes in age structure, household and family composition, social stratification (class structure) and dominant lifestyles (SAGE, J. et al. 2012b; Sмith, D.P. and Hubbard, P. 2014). Changes in the third dimension (cultural) are mostly the results of different consumption practices of students. As a result, certain types of retail and services appear in the neighbourhood creating new or transformed spaces of consumption. Finally, regarding the physical dimensions, it is often argued that studentification leads to an initial upgrading of the urban environment because of the investment of landlords, local authorities and other actors. However, this upgrading is usually followed by a downgrading process because of the lack of further investment which is often reflected by the decline of property prices (KENYON, E.L. 1997; Hubbard, P. 2009).

For the sake of analysis regarding the relationship between community cohesion and studentification, in our paper we try to match the above mentioned four dimensions of studentification with Forrest and KeARns' (2001) categorisation which identifies five domains of social cohesion: (1) common values and a civic culture; (2) social order and social control; (3) social solidarity and reductions in wealth disparities; (4) social networks and social capital; (5) place attachment and identity (Table 1).

Regarding the first domain, most of the relevant literature emphasise that in the process of studentification in-migrant young people represent lifestyles and cultural values which are distinctly different from those of the longterm residents. Such differences can easily become subjects of tensions and conflicts between the two social groups. Common moral principles and codes of behaviour, for example, are of key importance to a cohesive community, and established inhabitants often report on activities of students (e.g. the noise of night-time parties) which generate conflicts in the affected neighbourhoods. It is evident, therefore, that differences in behav- 
Table 1. The five domains of social cohesion*

\begin{tabular}{l|l}
\hline \multicolumn{1}{c|}{ Domain } & \multicolumn{1}{c}{ Description } \\
\hline $\begin{array}{l}\text { Common values and a civic } \\
\text { culture }\end{array}$ & $\begin{array}{l}\text { Common aims and objectives; common moral principles and codes of } \\
\text { behaviour; support for political institutions and participation in politics. }\end{array}$ \\
\hline $\begin{array}{l}\text { Social order and social } \\
\text { control }\end{array}$ & $\begin{array}{l}\text { Absence of general conflict and threats to the existing order; absence of } \\
\text { incivility; effective informal social control; tolerance; respect for difference; } \\
\text { intergroup co-operation. }\end{array}$ \\
\hline $\begin{array}{l}\text { Social solidarity and reduc- } \\
\text { tions in wealth disparities }\end{array}$ & $\begin{array}{l}\text { Harmonious economic and social development and common standards; } \\
\text { redistribution of public finances and of opportunities; equal access to } \\
\text { services and welfare benefits; ready acknowledgement of social obligations } \\
\text { and willingness to assist others. }\end{array}$ \\
\hline $\begin{array}{l}\text { Social networks and social } \\
\text { capital }\end{array}$ & $\begin{array}{l}\text { High degree of social interaction within communities and families; civic } \\
\text { engagement and associational activity; easy resolution of collective action } \\
\text { problems. }\end{array}$ \\
\hline $\begin{array}{l}\text { Place attachment and } \\
\text { identity }\end{array}$ & Strong attachment to place; intertwining of personal and place identity. \\
\hline
\end{tabular}

*According to Forrest, R. and Kearns, A. 2001.

iour of students and host communities can result in a hostile attitude between the two main groups (Hubbard, P. 2008; Sмith, D.P. 2011; Cochrane, A. and Williams, R. 2013).

Within the second domain, social conflicts and threats to existing social order and their management are in the focus. The increasing concentration of students can intensify the problems of noise, environmental disorder and pollution (Cochrane, A. and Williams, R. 2013). In addition, factors like changes in the local housing tenure system and property market pressure on established residents (especially the less affluent) often foster a general dissatisfaction among members of the local community. These effects can cause conflicts between students and long-term residents, leading to an emergence of anti-studentification movements and the decline of tolerance towards students (KENYON, E.L. 1997; Hubbard, P. 2006; National HMO Lobby, 2008; SAGE, J. et al. 2012b). At the same time, the seasonal occupancy of flats often attracts burglars to student concentrations, increasing crime rates and making such neighbourhoods high-risk areas (KenYon, E.L. 1997; Aluinson, J. 2006).

As for the third domain of social cohesion, the mass influx of students to a neighbourhood can diminish social solidarity and also increase wealth disparities in the area. As we pointed out earlier, studentification - often part of a gentrification process - frequently leads to the relocation of old residents from the affected areas, resulting in the split of established local social ties (Macintyre, C. 2003; Smith, D.P. 2004, 2005; Allinson, J. 2006; Sмiтh, D.P. and Holt, L. 2007). Moreover, it can produce new forms of social exclusion, new patterns of segregation by lifestyle, life-cycle, tenure type, economic capital (SMith, D.P. 2008; FinCHER, R. and Shaw, K. 2009; Hubbard, P. 2009; Chatterton, P. 2010), or even by activity and consumption types (Chatterton, P. 1999; Сhatterton, P. and Hollands, R. 2002). On the other hand, it is also worth mentioning that students can significantly contribute to local communities. For example, the acknowledgment of social obligationa and assisting others is an important factor within this domain, and volunteer work and charity are important elements of the activity spectrum in several student communities (Allinson, J. 2006; SMITH, D.P. and Denholm, J. 2006).

Within the fourth domain the quality of local social networks, social capital, interactions and civic engagement are to be analysed. It is important to stress that students as consumers can significantly contribute to the local 
economy - and their effects can be more salient in smaller towns or towns with high percentage of students (StEINACKer, A. 2005). Most of the students have notable free time, purchasing power and a vibrant social life. Therefore, they 'can help create lively, mixedcommunity neighbourhoods with an attractive mix of uses, high levels of local services, and vibrant cultural activities' (Munro, M. et al. 2009, p. 1808; see also: Macintyre, C. 2003; Allinson, J. 2006). However, some services such as schools can disappear from the neighbourhood, because of the changing local needs caused by the departure of families. It is also a well-known phenomenon that in-migrant students establish relationships mainly with other students when they seek friendship or accommodation (SмITH, D.P. and Holt, L. 2007; Hubbard, P. 2009). As a consequence, several neighbourhoods witness the sharp separation of established residents and students. Lessons from European social mixing policies have significant relevance at this point: the mixing of different groups does not necessarily lead to a real community (KeNYON, E.L. 1997; Boersma, K. et al. 2013). Nevertheless, according to Rogaly and TAYLOR (2015) permanent cohabitation can strengthen cohesion between students and established residents and produce new social ties among them.

Finally, the most serious barrier for students to embrace a strong place attachment and identity is the lack of time. First of all, student households have a temporary character, with residents spending only 6-9 months annually in the dwelling. Secondly, a large part of the students are transient inhabitants and after 3-5 years most of them continue their professional and housing career in other neighbourhoods or cities, and never come back. Thirdly, rapid turnover of renters in studentified areas seriously hampers the efforts to establish strong social ties with old residents (Allinson, J. 2006; Munro, M. et al. 2009). Such factors clearly work against a strong social cohesion at the neighbourhood level.

\section{Setting the scene: Józsefváros (Budapest) a 'diverse neighbourhood'}

Our research was carried out in Józsefváros, the $8^{\text {th }}$ District of Budapest (Figure 1). The district had 76,250 inhabitants on the eve of the 2011 census, of whom the proportion of non-Hungarians was high with 11.9 per cent (compared to Budapest's average of $4.8 \%$ ). The Gypsy/Roma is the largest ethnic minority group in the district, in some pockets they comprise around 40-50 per cent of the local population. There are also sizeable communities of international migrants (especially those coming from South Eastern Asia and Africa) in the district and particularly its central neighbourhoods are popular destinations for foreign (e.g. Chinese, Vietnamese) immigrants. Józsefváros is culturally the most diverse district of Budapest which is also widely acknowledged by local residents, media and policy documents.

Józsefváros has a highly diversified housing stock as well, which is the outcome of the multi-layered building activities since the middle of the $19^{\text {th }}$ century, and also the versatile regeneration activities having taken place since the late 1990s. The inner part of the district was built well before World War

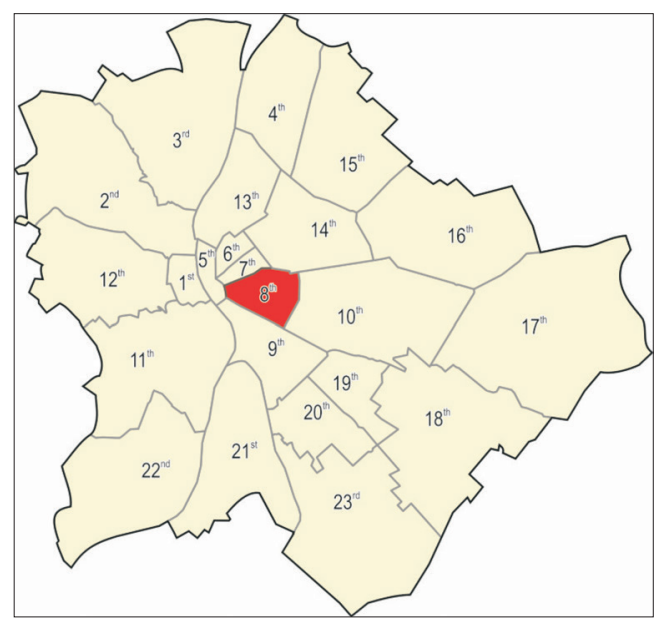

Fig. 1. Location of Józsefváros within Budapest 
I, with 3-4 storey tenement buildings. As an outcome of the communist slum clearance programme of the 1970s, pre-fab high rise buildings appeared in the area replacing some parts of the old dilapidated housing stock. From the late 1990s a large-scale slum clearance programme was launched, and the renovation of rundown buildings as well as the construction of new ones speeded up considerably (Photo 1).

Between the last two censuses (2001-2011) about 5,000 new (mostly upmarket) dwellings were added to the local housing stock of approximately 33,000 , which means a 12 per cent growth within a decade. This was one of the highest values among the 23 districts of Budapest during the period. The share of rental dwellings (both public and private) was 20.7 per cent in 2011, whereas it was only 10.6 per cent in Budapest. The weight of public housing was is the highest here in the city with 11.5 per cent in 2011 (compared to the Budapest average of $5.0 \%$ ).

Due to the extension of the housing stock and recent regeneration activities, above average residential mobility was recorded in Józsefváros. In Budapest, on the eve of the 2011 census 45 per cent of the residents had moved to his/her dwelling in the previous ten years, this figure was 52 per cent in Józsefváros. High level residential mobility has also brought about demographic and socio-economic changes. Even though - similarly to Budapest - the demographic profile of Józsefváros shows clear signs of ageing, yet, the share of younger households (singles, families with or without children) is higher than the city's average.

Newcomers who moved to Józsefváros after the turn of the millennium have clearly contributed to growing social and cultural diversity. Furthermore, due to immigration, the social status of the area has been slowly growing but this is spatially an uneven process; in some parts of the district it is more pronounced and more visible than in others. The most intense changes took place in the neighbourhoods that were transformed by local government led urban regenerations (e.g. Corvin Quarter near the Grand Boulevard) where the old housing

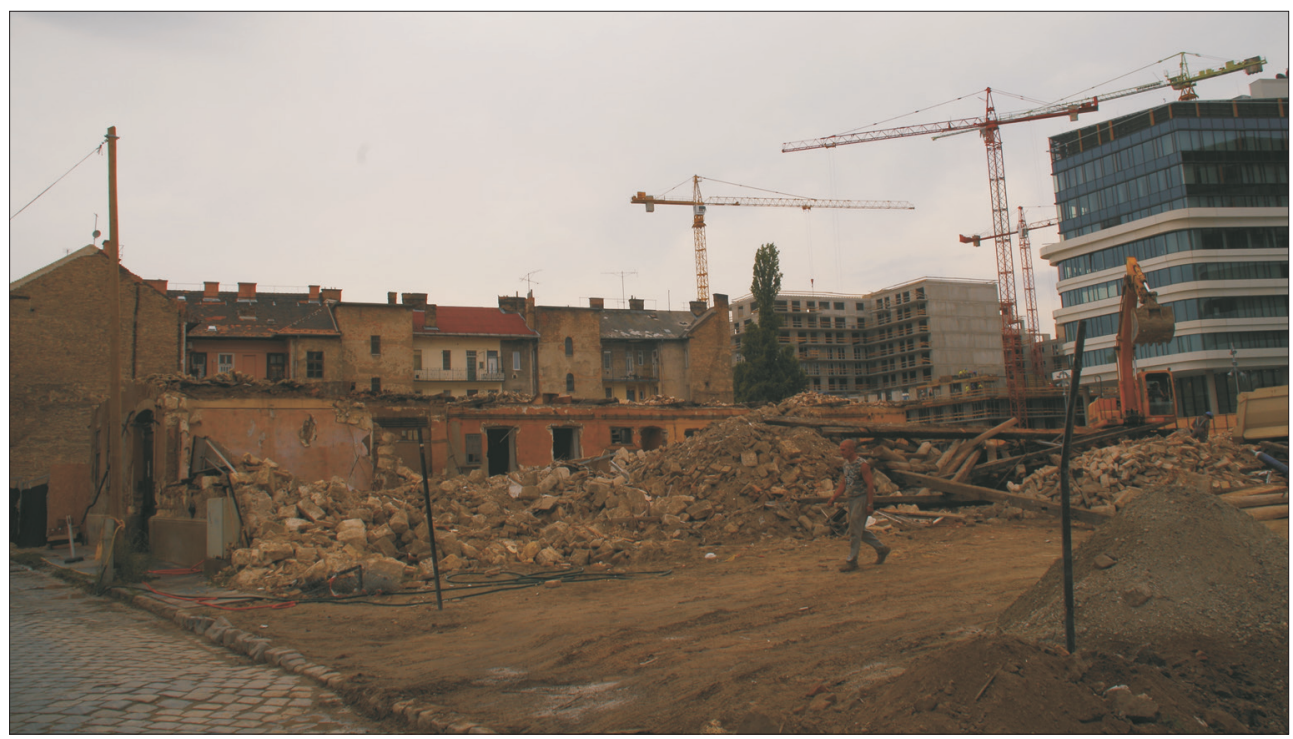

Photo 1. Large-scale, local government initiated regeneration activities in the centre of Józsefváros (Photo by Boros, L.) 
stock has been completely replaced by newly built apartments (new-build gentrification) (Photo 2).

The district is very attractive for students who can benefit from the great variety of rental dwellings and the affordable prices. As the Józsefváros Integrated Development Strategy emphasises, the district is a higher education centre with national significance since 10 per cent of the students studying in Hungary are enrolled at Józsefváros-bound institutions. The concentration of HEIs is also outstanding here: 11 universities and colleges with 18 faculties are located in the area [2]. This is an important driving force of the studentification process which goes hand in hand with other more classical forms of gentrification. Józsefváros with a diversified housing stock and hospitality and leisure facilities offers an ideal place for students between the 'boring' outskirts and the 'touristified' city centre.

To sum up, the quality of the housing stock in Józsefváros has significantly improved over the last two decades. New constructions and regeneration activities have brought about slow but steady influx of younger and partly higher-income households (Kovács, Z. et al. 2013). The previous negative image of Józsefváros has also improved as a result of urban regeneration activities, coupled with studentification and gentrification. The local government considers studentification as a useful tool for improving the reputation of the district and an essential element of urban rehabilitation - especially in the case of the new campus of the National University of Public Service (established in 2012) at the Orczy Quarter (Photo 3). Rising real estate prices can also partly be explained with the growing presence of students in the district (Czirfusz, M. et al. 2015; [1, 2, 3]).

\section{Research methods}

This paper is based on a series of in-depth interviews conducted with national- and citylevel policy makers, as well as residents and entrepreneurs of Józsefváros. The interviews

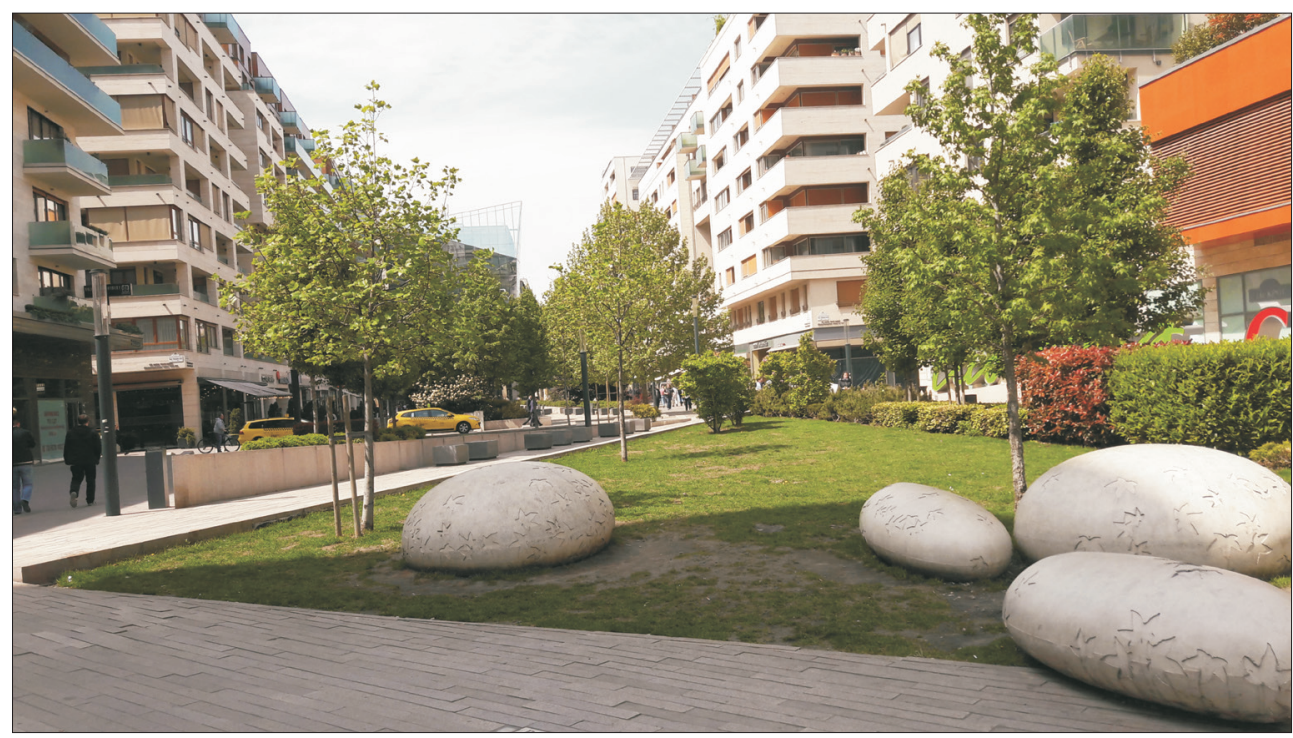

Photo 2. Corvin Promenade the epicentre of new-build gentrification in Józsefváros with upmarket dwellings and a new shopping mall (Photo by Kovécs, Z.) 


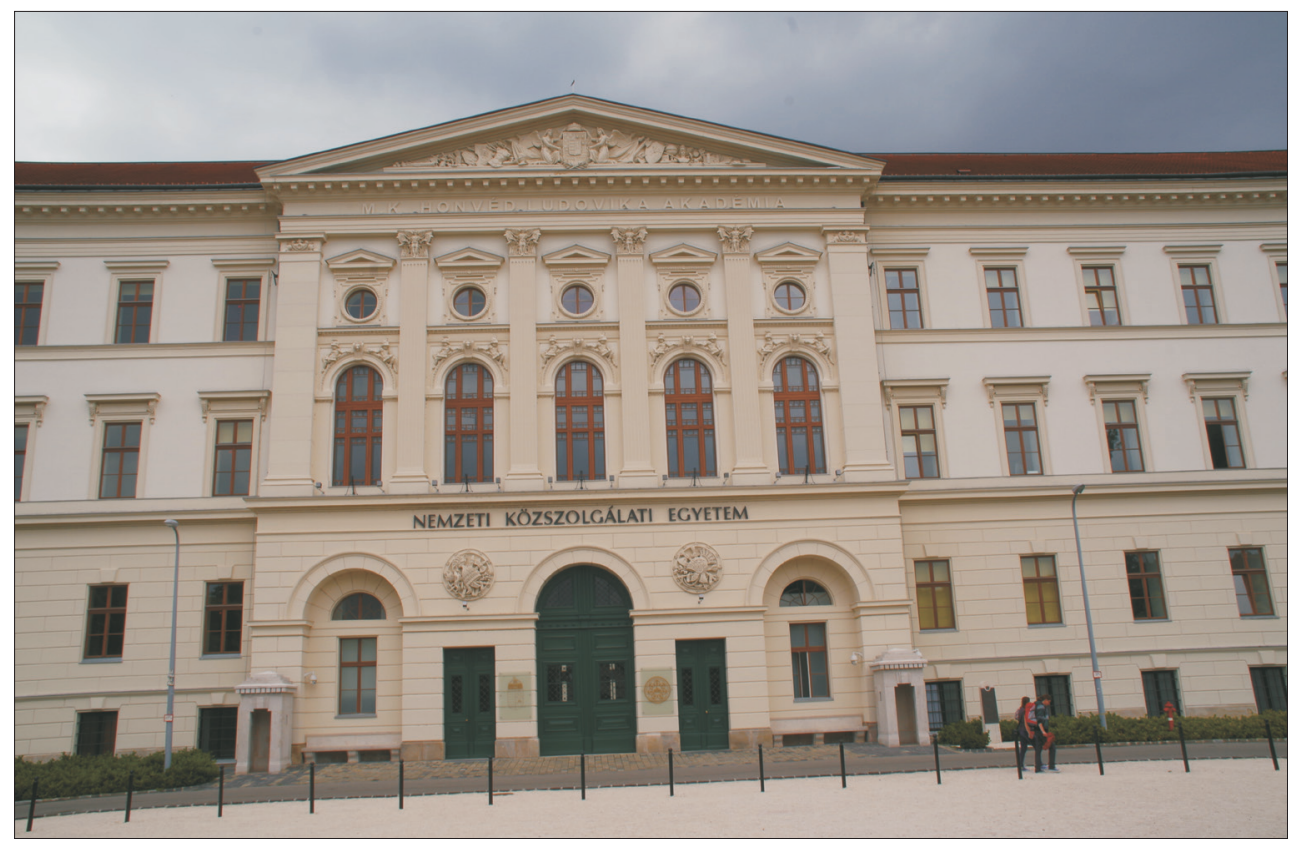

Photo 3. The new campus of the National University of Public Service accommodated in the $19^{\text {th }}$ century classicist building of a former military school (Photo by Boros, L.)

were undertaken within DIVERCITIES, a $7^{\text {th }}$ Framework Programme research project financed by the European Commission (full title: Governing Urban Diversity: Creating Social Cohesion, Social Mobility and Economic Performance in Today's Hyper-diversified Cities), between October 2013 and January 2016. Although DIVERCITIES was not specifically about studentification, yet, questions on the neighbourhood, the respondents' perceptions about the local society, their social ties and the role of local policies provided ample information on the topic.

For the sake of the study, a total of 109 indepth interviews (19 with policy-makers, 50 with residents, 38 with entrepreneurs and 2 with other experts) were analysed. The interviewees were recruited through three main channels. First, several policy-makers and entrepreneurs were directly approached after they had been identified as relevant potential respondents (e.g. through web search). Second, various institutions and key informants acted as entry points and mediated between us and the interviewees. For example, RÉV8 Plc. ${ }^{3}$ had a crucial role in this process, since this company had developed a broad social network in Józsefváros because of former regeneration projects and the active cooperation with local residents. Third, 'snowball sampling' was applied in some cases, mobilising local social ties to contact potential respondents.

During the recruitment of interviewees our aim was to compose a diverse but balanced sample for three sub-groups. The group of policy-makers consists of officials of the Hungarian central government and Budapest municipality as well as associates of non-governmental organisations. In the selection of the 50 residents a healthy mix was

${ }^{3}$ RÉV8 is a company founded by the local government of Józsefváros. Its primary aim is to manage local urban renewal programmes. 
achieved according to age, gender and educational attainment. As for their length of residence in Józsefváros, 26 persons moved to the district for twenty or more years (long-term residents), while 9 people moved there less than five years ago (newcomers - i.e. people moving to the area - have a vital role among the interviewees because of the ongoing gentrification process in Józsefváros). The group of entrepreneurs in our sample well reflects the heterogeneity of the economy of Józsefváros, including traditional handicraft shops (e.g. hat-maker), retailers (e.g. ethnic food stores), tourism and hospitality businesses (e.g. hotels, restaurants), consulting and engineering services (e.g. construction companies) and repair services (e.g. car mechanic).

\section{Main research findings}

We analyse here the relationship between studentification and social cohesion according to the five dimensions set by Forrest and Kearns (2001): (1) common values and a civic culture; (2) social order and social control; (3) social solidarity and reductions in wealth disparities; (4) social networks and social capital; (5) place attachment and identity. In doing so, our focus is mainly on how cohesion is manifested in these categories between students moving into Józsefváros and the long-term residents.

First of all, the values of long-term residents and newcomers are usually quite different in the district, however, their motivations to move or stay here is often similar: to exploit the good location of the district and the advantages provided by the reasonable rents and housing prices. This reflects to some extent the gateway function of the district which is beneficial for young people and students. But when it comes to goals, community development and possible initiatives, the opinion of newcomers and long-term residents differs - especially if we focus on the opinion of the most deprived social groups. The values and priorities of young people (including students) are very similar to those of early gentrifiers; they highlight the importance of safe and clean public spaces and highly appreciate the results of urban regeneration programmes.

"The situation around Calvin Square is untenable, homeless destroy so much the nicely renovated environment. [...] I do not like top-down measures or autocratic attitude but this should be handled somehow because seeing that people use squares as toilet is very disturbing." (Female, 29 years, teacher.)

On the other hand, long-term residents are more concerned about social issues, such as provision of public housing, job creation or social inequalities.

"There are a lot of empty apartments owned by investors or the local government while several people lost their homes due to loans and unpaid bills. In the house where my mother lives, there are four empty flats. Why not rent them to those who are trying to make their life better?" (Female, 30 years, street cleaner/public worker.)

Furthermore, in some cases, newcomers would like to see more changes or development, and get into conflict with established residents because of the alleged passivity of the latter group. This conflict can be manifested in a discourse characterised by dynamism-passivity dichotomy:

"I see the newcomers, the youngsters, who are motivated and dynamic but there are the elderly people who think differently. Obviously, they are another generation and their way of thinking is different." (Female, 32 years, real estate agent/developer.)

Participation in politics and local affairs is also different between the students and long-term residents. Most of the younger and newcomer residents said that they did not know anything about local community programmes. As a 25-year-old interviewee (male, private entrepreneur) answered the question whether he had any information on public initiatives: "No, not really, and I do not engage in such matters, because I do not see the meaning of these activities". Older residents are not very active politically either, even though, they are more engaged in local affairs - there- 
fore, shared visions, common political actions or initiatives are not manifested.

Regarding social order and social control, several conflicts are caused by the co-existence of various (sub)cultures and lifestyles in Józsefváros. The main conflicts caused by studentification are rooted in the generation gap in general and the conflicting needs of various age groups related to the use of public spaces in particular (Boros, L. et al. 2016). Student lifestyle includes activities like engagement in noisy leisure programmes, consuming higher amount of alcohol or sport activities, resulting in tensions with elderly, and more moderate inhabitants. Such conflicts are concentrated primarily in the inner parts of the district (Palota Quarter and Corvin Quarter) wherein the rate of elderly people as well as the concentration of student dwellings are higher than in other parts of Józsefváros. The owner of a restaurant and a hotel, for instance, referred to the different lifestyles of students and other residents, which difference has an effect on his business:

\footnotetext{
"They [students] move in at the beginning of the semester, start partying, making lots of noise when playing their music instruments at the middle of the night. But then other tenants teach them how to behave, and they fit in soon." (Male, 64 years, entrepreneur.)
}

In the district there are several initiatives that provide opportunities for intermixing for different social groups which might strengthen tolerance towards social difference. We mention here only two examples. The community garden of Leonardo (Photo 4 ), includes people with different age, gender, cultural background and qualifications e.g. brokers, foreigners, students, gypsy families, artists, pensioners, who get together for different activities in the summer season (Bende, Cs. and Nagy, Gy. 2016). The Gólya ruin-bar, created by young intellectuals, is an important meeting point for young intellectuals, artist, and urban activists (Photo 5). Both examples (community gardening and ruin-bars) are relatively recent phenomena in Budapest, they became important part of the local community and cultural life after 2000 (Lugosi, P.D. et al. 2010). However, how these initiatives bring together local people, it remains a question.

Regarding the third domain of social cohesion, social solidarity and reductions in wealth disparities, we can conclude that the economic performance of Józsefváros has improved a lot in the last decade and studentification contributed to this process significantly. Similarly to the experiences in the West, the in-migration of young people (among them university students) to Józsefváros contributes positively to the economic performance of the area through the appearance of new consumption groups, the renewal of the physical and economic environment, or the expansion of the local housing market. Both city- and district-level policy documents emphasise the favourable effects of the expansion of educational institutions and the growing number of students, for example, regarding the development of local tourism or the creative and innovative economic sectors (Egedy, T. and Sмiтh, M.K. 2016).

Moreover, for some local inhabitants one of the most positive results of the urban change is that the overall prestige of the area is rising. Therefore, these people welcome the influx of students and young families.

“Well, frankly I might see diversity rather positive because in the past the district was more homogeneous in a negative sense, but with the renewed blocks of flats and with the arrival of a wealthier, more qualified group the overall prestige of the neighbourhood has been rising. And from this point of view the growing social heterogeneity of the neighbourhood is a positive thing, I guess, because the former homogeneity was quite negative, and that meant mainly the presence of deprived, poor and criminal elements." (Male, 36 years, journalist.)

The economy of the district, however, develops socially and spatially very unevenly. There are robust wealth disparities among the different quarters of Józsefváros and social exclusion and marginalisation of some groups (e.g. the homeless, the poor, the Roma) is still a serious problem. 


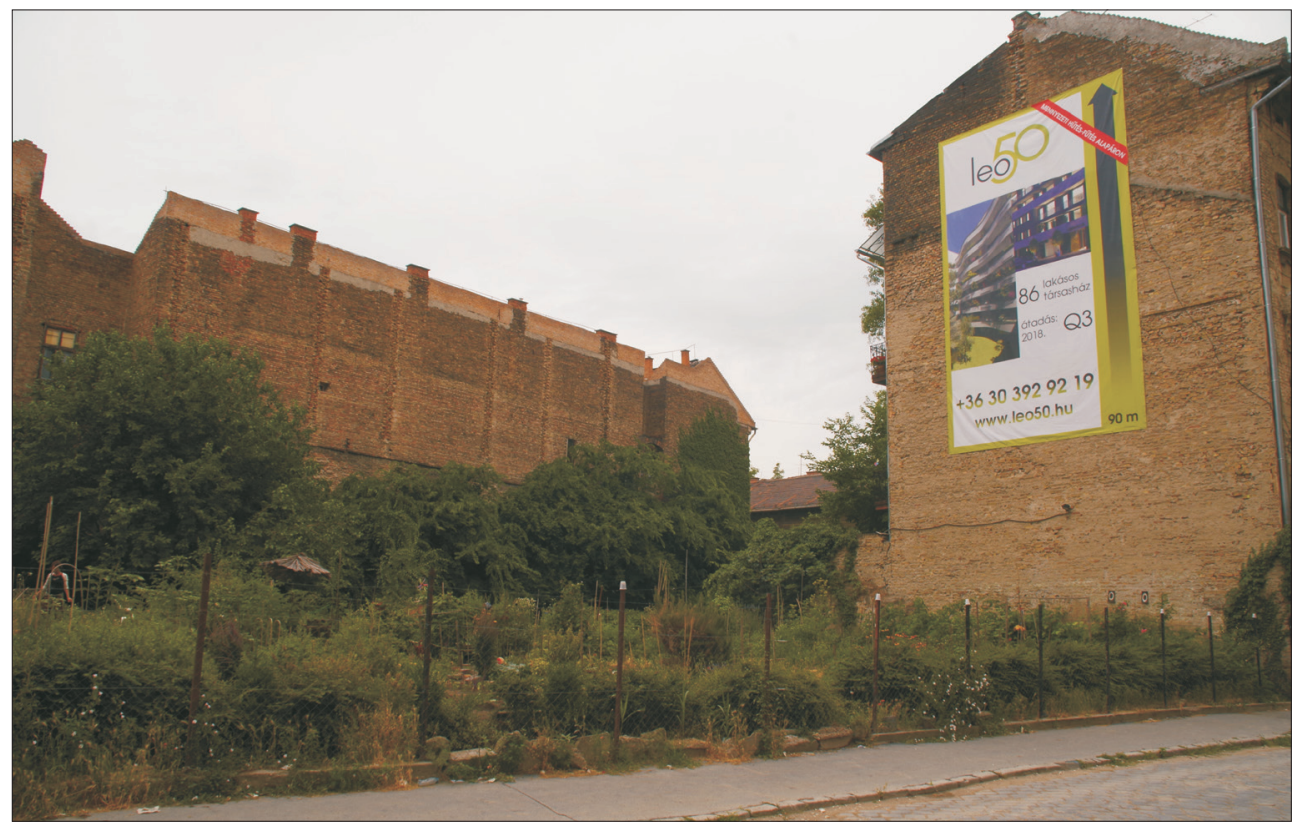

Photo 4. Leonardo community garden in the run-down neighbourhood provides an important meeting place for people with various background (Photo by Bonos, L.)

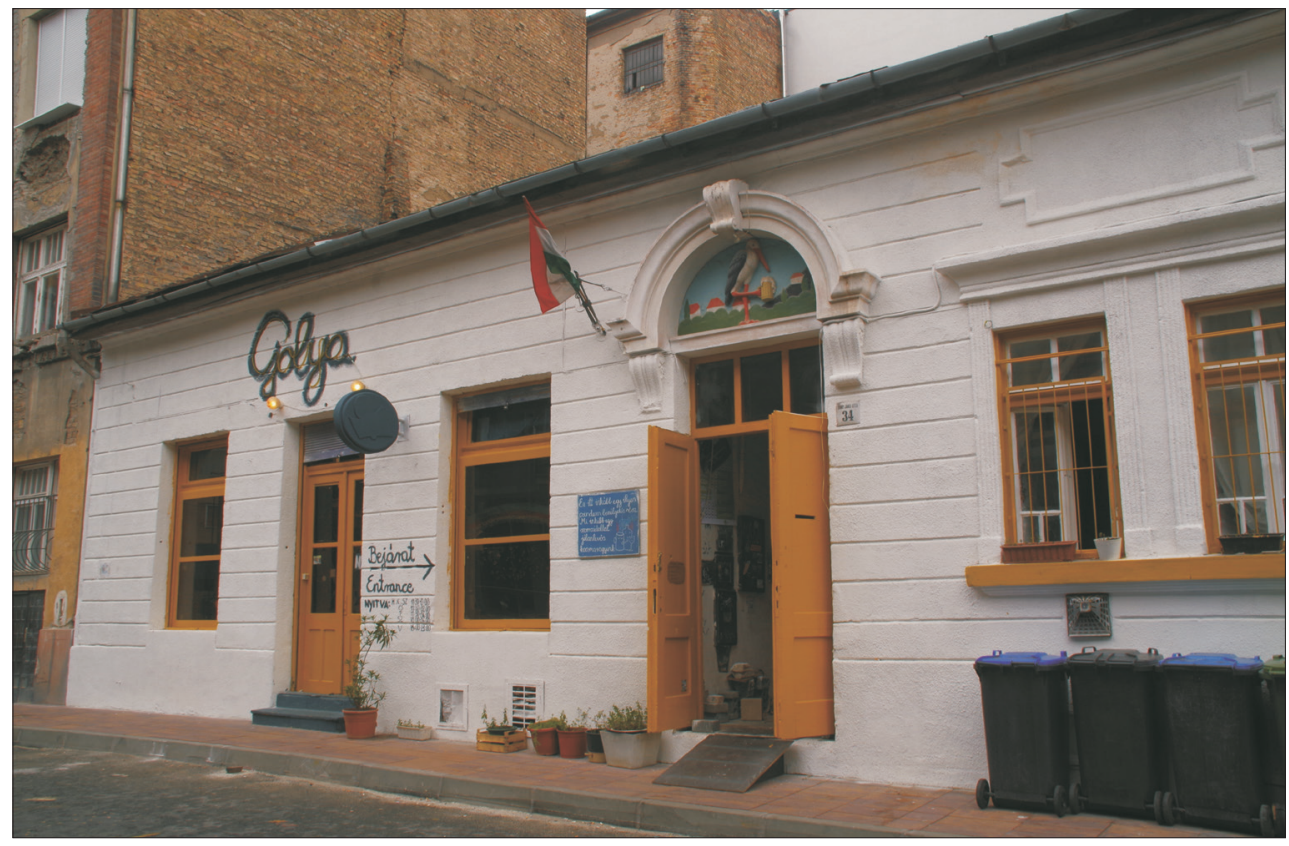

Photo 5. Gólya (it means stork in Hungarian) is the first "Communal House and Co-operative Presso" in Józsefváros organising concerts, literary nights, theatre workshops for young people (Photo by Boros, L.) 
"I think the entire neighbourhood has become younger and more affluent, since poor people had to relocate as a result of this whole on-going [renewal] project. So all of those who had lived here before in low quality public housing, have moved towards outer areas. And now they cannot come back to buy the dwellings which are much more expensive nowadays." (Female, 61 years, stylist/designer.)

We found weaker social cohesion within the district in neighbourhoods which have undergone intense regeneration such as the Corvin Quarter and other recently redeveloped residential areas where the population has changed dramatically. In these areas students and young professionals are important target group for the real estate developers:

“...what is really important factor (for investing here) is the vicinity of universities. [...] There is a high concentration of university buildings which is relatively unknown at this time. But within a few years the penetration of health care and IT professionals will be exceptional." (Male, 38 years, real estate developer.)
The fluctuation of residents according to age and social status generates wider social differences as well as a polarisation within the society. It negatively affects the possibility of creating interactions among neighbours (horizontal connections) and among different social groups (vertical relations) as well.

"There are 14 apartments in our old building, but only nine of them are occupied. Half of the residents are elderly people and the rest are young - they are under 35 and have moved in during the past few years. The middle-aged are missing in the block ... I have very limited contact with my neighbours. If I welcome somebody or ask them 'how are you?', it already means a closer relationship." (Male, 30 years, private entrepreneur: programmer/website designer.)

According to our findings, the consumption practices and patterns of students and long-term residents are quite different which is a significant element of the parallel lives of various age/social groups (Photo 6).

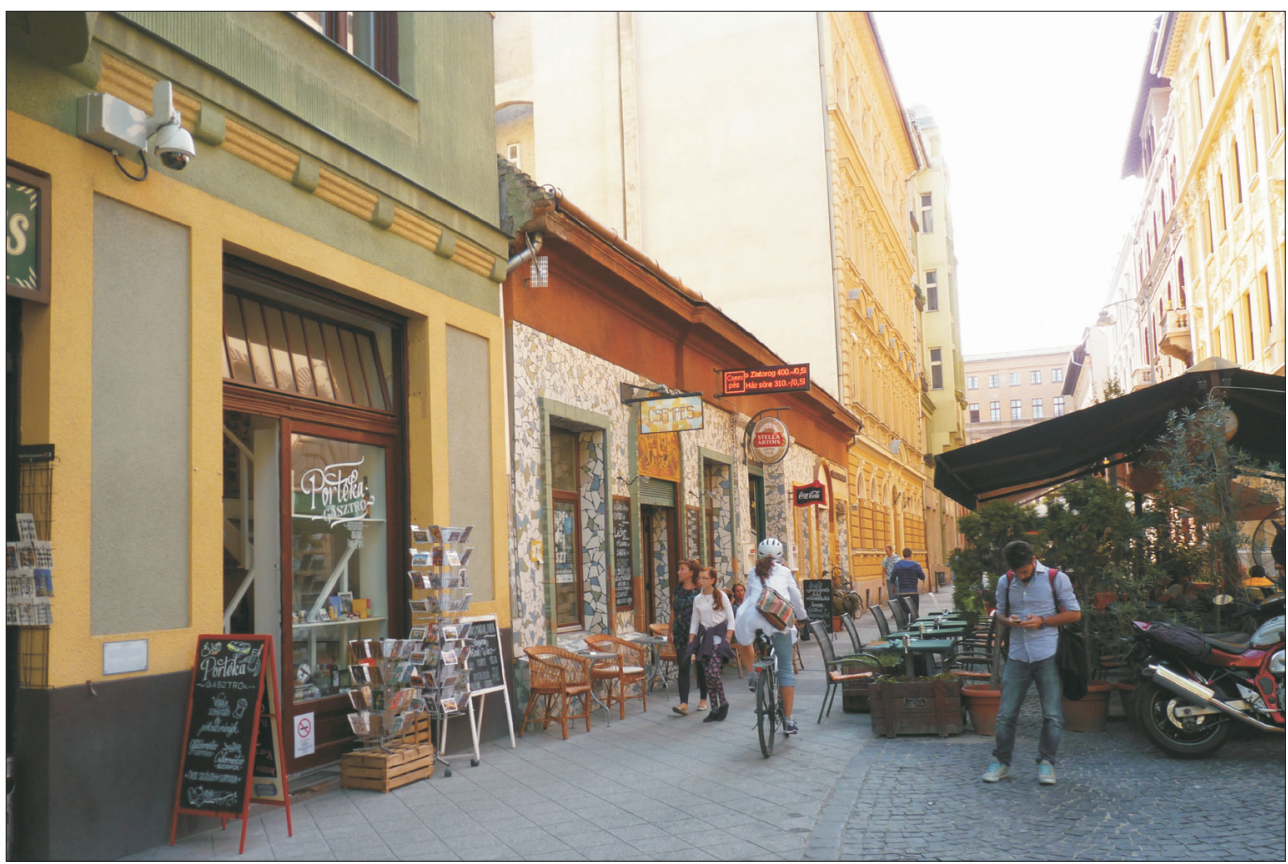

Photo 6. Typical consumption spaces of students and young intellectuals in the inner-part of Józsefváros (Photo by Fabula, Sz.) 
The separation of consumption decreases the chances of interaction and the development of personal relationships. In some cases, the different consumer base of businesses is a result of some kinds of 'repositioning' of enterprises (e.g. bars, restaurants, shops). The consumption gap between foreign students (with higher purchasing power) and locals is especially remarkable:

“... there are cafés with such high prices that I cannot imagine who can afford it among the locals, among Hungarians. Their consumers are the foreign students." (Male, 51 years, entrepreneur.)

The on-going internationalisation of Hungarian higher education will most probably strengthen and make more visible these differences in the future. Several new enterprises (e.g. start-up ventures) aim to exploit the vicinity of universities and offer job opportunities for students or newly graduated career starters. Since the older, established residents cannot utilise these opportunities, the wealth and income disparities may widen between old and new residents.

\footnotetext{
"We chose this office because we can hire students, who can work here between classes and exams. [...] I think, Józsefváros is a promising area because of the vicinity of universities." (Female, 39 years, start-up entrepreneur.)
}

Some of the literature on studentification point out, that the growing concentration of university students in a neighbourhood can lead to a general neglect of social obligations and the quality of the urban environment (see e.g. Kenyon, E.L. 1997). Nevertheless, as one of the established residents, who has been living in Józsefváros for more than ten years, noted it is not necessarily the case:

\footnotetext{
"Many young people have moved in and honestly I am happy about that, because they pay the common fees of the building regularly and they take care about their environment more than the former residents." (Female, 37 years, dispatcher.)
}

As far as the fourth dimension of social cohesion is concerned, we found that the pro- cess of studentification has straightforward impacts on the social networks and social cohesion of the district. The personal networks of students and young newcomers are very much different from those of the older and long-term residents. Obviously, latter tend to have more and stronger local connections than newcomers - which confirms the findings of Guest and Wierzbicki (1999). Since the newcomers' personal networks extend well outside the boundaries of Józsefváros they usually keep contacts and exchange help with people living outside the district.

Although family ties are the most important among personal networks, similar lifestyle and stage in the life-cycle increase the chance of developing bonds and providing mutual help among residents. This observation highlights the importance of differentiation between social, cultural and age groups when analysing social ties (Forrest, R. and KeARns, A. 2001), since solidarity and mutual help is more likely to work within groups than between members of different social and cultural groups.

This is similar to the findings of VAN BeckHoven and van Kempen (2003): in most cases the residents mostly live along each other not together ('parallel lives'). On the one hand, trust and support are manifested on the scale of the house or block. On the other hand, the spatiality of the personal networks (i.e. friends and family) has a significant role in developing and maintaining supportive relationships and these cannot be connected to a particular scale or neighbourhood.

Regarding place attachment and identity we found that our case-study area (Józsefváros) is a typical inner-city district where historical traditions are well-perceived by local people, most of whom have a distinct 'Józsefváros identity'. Within our sample clear distinction could be made between long-term residents and newcomers (i.e. students, young gentrifiers) in this respect. For the latter group increased mobility and lower level of placeattachment is a significant obstacle to more intense social contacts: 


\begin{abstract}
"Here a newcomer group settled in which had been targeted [by developers and real estate agents] so that new apartments would be purchased by young middle-class people; but in general they do not like the $8^{\text {th }}$ District. They do not come here by real choice in most cases but because they can afford only these dwellings... Therefore, I do not think they really identify themselves with this neighbourhood." (Female, 42 years, consular officer and interpreter.)
\end{abstract}

\section{Discussion and conclusions}

The principal aim of this study was to examine the effects of studentification on urban diversity and social cohesion in the post-socialist Hungarian context. Our first research question was: how studentification is related to the gentrification in the case-study area of Józsefváros? According to our findings, studentification in Józsefváros is not the pioneer phase of gentrification, but - especially in the rehabilitation areas - it runs more or less parallel with it. In this respect it shows certain differences compared to other post-socialist and Western experiences.

Firstly, because physical upgrading in the originally dilapidated district has been taking place for quite a while (10-15 years). The built environment has gone through spectacular changes, the local economy substantially strengthened, new functions (i.e. higher education, shopping, leisure, hospitality industry) settled to the area. As a consequence, a lot of young people, among them students, discovered the district, and moved here. The spatial pattern of studentification has also changed accordingly. Earlier it had a dispersed spatial pattern like in other post-socialist cities (see Murzyn-Kupisz, M. and Szmytkowska, M. 2015), but due to the excessive urban rehabilitation programmes studentification (and also gentrification) has become geographically very much concentrated. The mushrooming of ruin-bars and other cultural and leisure facilities also strengthens the spatial concentration of students. Thus, the spatial separation of housing, education and leisure (nightlife) activities of students is not that strong in the Budapest case as in other post-socialist cities.
Secondly, since the district is subject of robust (state-led) regeneration activities, newcomers are coming mainly from outside the district and Budapest (partly from abroad). They have no place attachment at all, and consider their stay temporary and reside in the district as transitory urbanites (HAASE, A. et al. 2012). Most of the students use the place as a springboard in their career, and after graduation most of them leave. The attitude of students is, however, very much resembles those of the young, highly educated newcomers, i.e. early gentrifiers.

The second research question concerned the impacts of the influx of students on the social cohesion of Józsefváros. In the present stage of urban transformation studentification clearly contributes to the demographic, cultural, social and economic diversity of Józsefváros. However, its effects are perceived very differently by the local residents, depending on factors like location, social status and professions (i.e. 'ordinary residents' versus entrepreneurs). Residents living outside the core area of regeneration often mention the lack of interaction between newcomers and long-term residents, while also highlighting the role of different attitudes and lifestyles. At the same time residents of the renovated areas who are mostly new inhabitants do not perceive any weakening in social cohesion, since they have not got previous experiences regarding the local society. The interrelation between studentification, neighbourhood diversity and social cohesion is clear: those parts of Józsefváros which have not been affected by regeneration activities and notable student influx are more cohesive.

Our empirical research identified several factors that hamper the development of a cohesive society: the significant difference in lifestyles and values, high level of socio-spatial inequalities, intense population turnover and the exclusion of less-affluent residents, or the weak place attachment of the new residents.

Nevertheless, Józsefváros and its population can profit from other processes which can also foster cohesion in the area, e.g. ac- 
knowledgment of diversity and acceptance of otherness as a result of increasing social mix, the diversification of the housing stock, the contribution of students to the community's living costs and local developments.

Studentification has been used actively by the local government to improve the image of the district. The growing number of students and higher education institutions is portrayed as an asset of Józsefváros in local policy documents.

However, there are also factors that may hamper the future continuation of studentification. Once the value gap reaches a certain level and the area becomes simply overvalued by the market much harder forms of gentrification can sweep away the existing student enclaves. Or, some parts of the housing stock become utilised for other purposes e.g. tourism. Right now there are obvious signs of this phenomenon in the inner part of the district where relatively high share of dwellings is used for Airbnb purposes (DudÁs, G. et al. 2016). These developments will threaten even more the social cohesion of Józsefváros than studentification.

Acknowledgements: This project has received funding from the European Union's Seventh Framework Programme for research, technological development and demonstration under Grant Agreement No 319970 - DIVERCITIES. The views expressed in this publication are the sole responsibility of the authors and do not necessarily reflect the views of the European Commission. The work of Lajos Boros was supported by the János Bolyai Research Scholarship of the Hungarian Academy of Sciences, and Zoltán Kovács received funding from the Hungarian Scientific Research Fund (OTKA) Grant Agreement No. K 119710.

\section{REFERENCES}

Allinson, J. 2006. Over-Educated, Over-Exuberant and Over Here? The Impact of Students on Cities. Planning, Practice E Research 21. (1): 79-94.

Bende, Cs. and Nagy, Gy. 2016. Közösségi kertek Szegeden - Empirikus vizsgálatok és esettanulmányok (Community gardens in Szeged - an empirical research and case studies). Földrajzi Közlemények 140. (1): 55-72.
Bernt, M., Gentile, M. and MarcińczaK, S. 2015. Gentrification in post-communist countries: An Introduction. Geografie 120. (2): 104-112.

Boersma, K., Langen, H. and Smets, P. 2013. Paradoxes of Studentification: Social Mix versus Gentrification in a Disadvantaged Neighborhood in Amsterdam East. The Open Urban Studies Journal 6. (Suppl. 1. M3): 40-49.

Boros, L., Fabula, Sz., Horváth, D. and Kovács, Z. 2016. Urban diversity and the production of public space in Budapest. Hungarian Geographical Bulletin 65. (3): 209-224.

Chatterton, P. 1999. University students and city centres - The formation of exclusive geographies. The case of Bristol, UK. Geoforum 30. (2): 117-133.

Chatterton, P. 2010. Commentary: The student city: an ongoing story of neoliberalism, gentrification, and commodification. Environment and Planning $A$ 42. (3): 509-514.

Chatterton, P. and Hollands, R. 2002. Theorising Urban Playscapes: Producing, Regulating and Consuming Youthful Nightlife City Spaces. Urban Studies 39. (1): 95-116.

Cochrane, A. and Williams, R. 2013. Putting higher education in its place: the socio-political geographies of English universities. Policy and Politics 41. (1): 43-58.

Coulter, R., van Ham, M. and Findlay, A.M. 2015. Rethinking residential mobility: Linking lives through time and space. Progress in Human Geography, 23. Doi: 10.1177/030913 2515575417

Czirfusz, M., Horváth, V., Jelinek, Cs., Pósfai, Zs. and Szaвó, L. 2015. Gentrification and rescaling urban governance in Budapest-Józsefváros. Intersections 1. (4): 55-77.

Davidson, G. 2009. Carlton and the campus: the university and the gentrification of inner Melbourne 1958-75. Urban Policy and Research 27. (3): 253-264.

Dudás, G., Boros, L. and PÁL, V. 2016. Közösségi szállásadás Budapesten - Az Airbnb térnyerése (Peer-topeer accomodations in Budapest - The expansion of Airbnb). Településföldrajzi Tanulmányok 5. (3-4): 66-83.

Egedy, T. and SMith, M. K. 2016. Old and new residential neighbourhoods as creative hubs in Budapest. Mitteilungen der Österreichischen Geographischen Gesellschaft 158. 85-108.

Fincher, R. and SHAw, K. 2011. Enacting separate social worlds: "international" and "local" students in public space in central Melbourne. Geoforum 42. (5): 539-549.

Forrest, R. and Kearns, A. 2001. Social Cohesion, Social Capital and the Neighbourhood. Urban Studies 38. (12): 2125-2143.

Gentile, M., Tammaru, T. and Van Kempen, R. 2012. Heteropolitanization: social and spatial change in Central and East European Cities. Cities 29. (5): 291-299. 
GórCzý́sKA, M. 2014. Unique of universal? Mechanisms and processes of social change in post-socialist Warsaw. Hungarian Geographical Bulletin 31. (3): 255-277.

GórCZyŃsKa, M. 2017. Gentrifiers in the post-socialist city? A critical reflection on the dynamics of middleand upper-class professional groups in Warsaw. Environment and Planning A 49. (5): 1099-1121.

Grabkowska, M. 2011. Inner-city transformations after socialism. Findings from interviews with new residents of pre-war tenement houses in Gdansk. Bulletin of Geography, Socio-Economic Series 15. 117-129.

Grabkowska, M. and Frankowski, J. 2016. 'Close to the city centre, close to the university'. Are there symptoms of studentification in Gdańsk, Poland? Bulletin of Geography, Socio-Economic Series 32.73-83.

Guest, A.M. and Wierzbicki, S.K. 1999. Social ties at the neighborhood level: two decades of GSS evidence. Urban Affairs Review 35. (1): 92-111.

HaAse, A., Grossman, K. and Steinführer, A. 2012. Transitory urbanites: New actors of residential change in Polish and Czech inner cities. Cities 29. (5): 318-326.

Hubbard, P. 2006. NIMBY by another name? A reply to Wolsink. Transactions of the Institute of British Geographers 31. (1): 92-94.

Hubbard, P. 2008. Regulating the social impacts of studentification: a Loughborough case study. Environment and Planning A 40. (2): 323-341.

Hubbard, P. 2009. Geographies of studentification and purpose-built student accommodation: leading separate lives? Environment and Planning A 41. (8): 1903-1923.

JaKóвсzyк-Gryszkiewicz, J., MarcińcZaK, S. and WolANIUK, A. 2014. Gentrification processes in the city. In Society and Space in Contemporary Poland in Łódź University Geographical Research. Ed.: MarszaŁ, T., Łódź, Łódź University Press, 83-111.

Kährik, A., Temelová, J., Kadarik, K. and Kubeš, J. 2016. What attracts people to inner city areas? The cases of two post-socialist cities in Estonia and the Czech Republic. Urban Studies 53. (2): 355-372.

KenYon, E.L. 1997. The impact of student households on residential communities. The British Journal of Sociology 48. (2): 286-301.

Kovács, Z., Wiessner, R. and Zischner, R. 2013. Urban renewal in the inner city of Budapest: Gentrification from a post-socialist perspective. Urban Studies 50. (1): 22-38.

KRIŠJĀNE, Z. and BĒRZIN̦š, M. 2014. Intra-urban residential differentiation in the post-Soviet city: The case of Riga, Latvia. Hungarian Geographical Bulletin 63. (3): 235-253.

LEY, D. 2003. Artists, aestheticisation and the field of gentrification. Urban Studies 40. (12): 2527-2544.
Lugosi, P., Bell, D. and Lugosi, K. 2010. Hospitality, culture and regeneration: Urban decay, entrepreneurship and the 'ruin' bars of Budapest. Urban Studies 47. (14): 3079-3101.

Macintyre, C. 2003. New models of student housing and their impact on local communities. Journal of Higher Education Policy and Management 25. (2): 109-118.

Munro, M., Turok, I. and Livington, M. 2009. Students in cities: a preliminary analysis of their patterns and effects. Environment and Planning $A$ 41. (8): 1805-1825.

Murzyn-Kupisz, M. and Szmytkowska, M. 2015. Studentification in the post-socialist context: The case of Cracow and the Tri-City (Gdansk, Gdynia and Sopot). Geografie 120. (2): 188-209.

National HMO Lobby 2008. Balanced Communities and Studentification. Leeds, National HMO Lobby.

Rogaly, B. and Taylor, B. 2015. For the likes of us? Retelling the classed production of a British university campus. ACME: An International E-Journal for Critical Geographies 14. (1): 235-259.

RugG, J. and Rhodes, D. 2003. 'Between a rock and a hard place': The failure to agree on regulation for the private rented sector in England. Housing Studies 18. (6): 937-946.

RugG, J., Rhodes, D. and Jones, A. 2002. Studying a niche market: UK students and the private rented sector. Housing Studies 17. (2): 289-303.

Russo, A.P., van der Berg, L. and Lavanga, M. 2003. The student city. Strategic planning for student communities in EU cities. Paper submitted to the R-sections of the $43^{\text {rd }}$ European Congress of the Regional Science Association, Jyväskylä, Finland, August 27-30.

Sage, J., Smith, D.P. and Hubbard, P. 2012a. The diverse geographies of studentification: living alongside people not like us. Housing Studies 27 (8): 1057-1078

Sage, J., Smith, D.P. and Hubbard, P. 2012b. The rapidity of studentification and population change: There goes the (student)hood. Population, Space and Place 18. (5): 597-613.

Sмiтh, D.P. 2002. Patterns and processes of "studentification" in Leeds. The Regional Review 12. (1): 14-16.

Sмгтн, D.P. 2004. Geographies of studentification and 'apprentice' gentrifiers. Peer-reviewed paper presented at the $7^{\text {th }}$ Pan-Hellenic Geographical Conference of the Hellenic Geographical Association, University of Lesvos, Greece. Accessed at: http://srcosmos. gr/srcosmos/showpub.aspx?aa $=6348$

Sмiтh, D.P. 2005. "Studentification": the gentrification factory? In Gentrification in a Global Context. The New Urban Colonialism. Eds.: Atkinson, W.R. and Bridge, G., London, Routledge, 72-89. 
Sмiтh, D.P. 2008. The politics of studentification and '(un)balanced' urban populations: Lessons for gentrification and sustainable communities? Urban Studies 45. (12): 2541-2564.

Sмiтh, D.P. 2011. Geographies of long-distance family migration: Moving to a 'spatial turn'. Progress in Human Geography 35. (5): 652-668.

Smith, D.P. and Denholm, J. 2006. 'Studentification': a guide to opportunities, challenges and practice. London, Universities UK.

Smith, D.P. and Holt, L. 2007. Studentification and 'apprentice' gentrifiers within Britain's provincial towns and cities: extending the meaning of gentrification. Environment and Planning A 39. (1): 142-161.

Smith, D.P. and Hubbard, P. 2014. The segregation of educated youth and dynamic geographies of studentification. Area 46. (1): 92-100.

Steinacker, A. 2005. The Economic Effect of Urban Colleges on their Surrounding Communities. Urban Studies 42. (7): 1161-1175.

Van Beckhoven, E. and van Kempen, R. 2003. Social effects of urban restructuring: a case study in Amsterdam and Utrecht, the Netherlands. Housing Studies 18. (6): 853-875.

ZukIN, S. 1989. Loft Living: Culture and Capital in Urban Change. New Brunswick, Rutgers University Press.

\section{OTHER SOURCES:}

[1] Municipality of Budapest 2015. Local Economy Development Strategy of Budapest 2015-2021. Budapest, Municipality of Budapest.

[2] Pest-Budapest Konzorcium 2015. Józsefváros Integrált Településfejlesztési Stratégia-Megalapozó vizsgálat (Józsefváros Integrated Urban Development Strategy - Baseline Report). Budapest, Budapest Főváros VIII. kerület Józsefvárosi Ônkormányzat.

[3] NKE 2014. Az Orczy-negyed rehabilitációja (The rehabilitation of Orczy Quarter). Budapest, NKE Szolgáltató Kft. 
